\begin{tabular}{|c|c|}
\hline 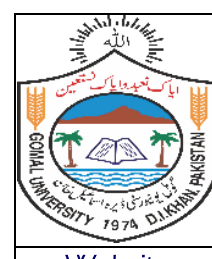 & $\begin{array}{l}\text { GOMAL UNIVERSITY } \\
\text { JOURNAL OF RESEARCH } \\
\text { Gomal University, Dera Ismail Khan, Khyber Pakhtunkhwa, Pakistan } \\
\text { isSN: } 2708-1737 \text { (15nline) }\end{array}$ \\
\hline & \begin{tabular}{l|l|l|l|l} 
quif.com.pk & HEC Recognized & Social Sciences & CrossRef \\
\end{tabular} \\
\hline
\end{tabular}

\title{
RELATIONSHIP OF SHYNESS WITH LIFE SATISFACTION: THE MEDIATING ROLE OF CAREER SUCCESS
}

\author{
Waseem Ullah', Abdul Khaliq Alvi² \& Muhammad Akram Soomro ${ }^{3}$ \\ 'School of Management and Economics, Kunming University of Sciences \& Technology, CHINA \\ 2Department of Management Sciences, Lahore Garrison University, Lahore, Pakistan \\ ${ }^{3}$ Department of Mass Communication, The University of Punjab, Lahore, Pakistan
}

\begin{tabular}{|c|c|}
\hline KEWWORDS & ABSTRACT \\
\hline $\begin{array}{l}\text { Shyness, Life } \\
\text { Satisfaction, Career } \\
\text { Success, Telecom } \\
\text { Sector }\end{array}$ & \multirow{3}{*}{$\begin{array}{l}\text { This research study describes the mediating effect of career success for the } \\
\text { relationship of shyness with life satisfaction. Current research is based on } \\
\text { employees of telecom sector of Lahore Pakistan. Current research proposes } \\
\text { four hypotheses. } 252 \text { employees of telecom sector are randomly selected } \\
\text { for collecting data. Three of the hypotheses are about direct relationships } \\
\text { and one is about the mediation effect of career success for the relation of } \\
\text { shyness with life satisfaction. The study provided the significant results in } \\
\text { reaching the conclusion. All the hypotheses are accepted. Moreover, the } \\
\text { career success partially mediates relation of shyness with life satisfaction. In } \\
\text { future, these types of studies may also conduct on other sectors like the } \\
\text { banking sector; textile sector and education sector for validate the results. It } \\
\text { is also worthwhile to collect the data from employees of the Government } \\
\text { sector of employees. For generalizing the results data will also collect cities } \\
\text { like Islamabad, Faisalabad and Karachi. }\end{array}$} \\
\hline Article History & \\
\hline $\begin{array}{l}\text { Date of Submission: } \\
\text { 10-03-2021 } \\
\text { Date of Acceptance: } \\
\text { 16-06-2021 } \\
\text { Date of Publication: } \\
\text { 30-06-2021 }\end{array}$ & \\
\hline Corresponding Author & Waseem Ullah: samwestmidland@gmail.com \\
\hline $\mathrm{DOI}$ & https://doi.org/10.51380/gujr-37-02-04 \\
\hline
\end{tabular}

\section{INTRODUCTION}

According to Diener, Emmons, Larsen and Griffin (1985) life satisfaction is basically broader thinking about the individual's life, how much he/she is satisfied and it can be judged through individual quality of life and peace of mind. As per suggestions of Hintikka, Koskela, Kontula, Koskela, Honkanen and Viinamäki (2001) and Sun and Shek (2012) decreased level of the life satisfaction may become reason for the negative behaviors and down emotions like disheartens, suicide attempts, wild and abusing behavior. The study of Diener, Scollon, Oishi, Dzokoto and Suh (2000) reflects that people from different culture and background reacts in the different way about the concept of life satisfaction for example the Chinese college level students relates the shyness with the life satisfaction. Available studies about the Chinese college level students mainly focus on understanding of general satisfaction (Zhang, Zhang \& Hudson, 2018). Cheek 
and Buss (1981) have defined shyness as characteristic of a human, which is situation of being remain reserve and feeling discomfort in social setup. It is linked with hidden participation in certain activities to pursue the career goals effectually (Li, Chi, Zhang, Cheng, Zhang \& Chen, 2015).

According to Rohrer, Richter, Brümmer, Wagner and Schmukle (2018), Nie, Tian and Huebner (2019) and Xiang, Yuan and Zhao (2020) previous studies have identified that shyness can be predicted through social anxiety, in general pathological usage of internet, problem in mobile usage and loneliness. Study of Sun and Shek (2010) disclosed that shyness can easily observed within Chinese college level students instead of other countries. Prior researches also suggest that shyness describe about basic personality characteristic such as neurotic and introverted attributes of the personality (Han \& Hong, 2011) and same kind of the personality traits can be identified among victims of bullied individuals (Maynard \& Joseph, 2008). As per Ren, Folmer and Vlist (2018) Shyness can be observed in college students with high level and they can be easily bullied because of the emotional instability, introversion and poor communication capabilities. Shy individuals type cannot easily adjust in the social setting (Henderson, Gilbert \& Zimbardo, 2014), due to that reason shy student of college does have lesser life satisfaction (Erol \& Orth 2017). Rowsell and Coplan (2013), Canadian college student and concluded that shyness do have indirect link with psychological well-being. Among population of Chinese, college students also have inverse relation with subjective well-being (SWB) (Wang \& Kong, 2014).

The cognitive component of "subjective well-being refers to life satisfaction that is a subjective evaluation of overall quality of life (Diener, 1985), as crucial indicator of SWB, life satisfaction plays key role in lives of adolescents and emerging adults (Wang, Tian, Guo \& Huebner, 2020), although the relationship between shyness and life satisfaction has been well established (Erol, 2017), the potential reason underlying this relationship remains unclear, testing moderated mediation models among college students may help explaining the reason as to how shyness negatively related to life satisfaction and exploring mediating and moderating factor underlying this association could advance our understanding of how and when shyness may be employed in order to promote college students' life satisfaction”. According to Gigantesco et al. (2019) it is compulsory to analyze the certain mediating type variables among this specific relationship. Siebert, Kunz and Rolf (2020) suggested that the successful career is based on psychological outcomes and such as positive work as the experience gained. Organizational practitioners and researchers have focused on impact of career success (Lee, 2020). To determine ensuing effects of career success, link among life satisfaction and career success has attained huge intention because it is being found that career is the core affecting component for the life satisfaction (Ferrer, 2017), which reflects the detailed analysis about their lives (Keyes Shmotkin \& Ryff, 2002).

\section{LITERATURE REVIEW}

Some empirical results shows that link among the life satisfaction and career success is positive (Diener \& Diener, 2009; Zhang \& Howell, 2011) and some other shows the negative (Judge \& Mueller, 2012; Pan \& Zhou, 2013; Tremblay, Dahan \& Gianecchini, 2014). Such inconsistent results disclosed the need of further research to identify when and how the career success is positively linked with life satisfaction of employee. According to Jawahar and Liu (2017) prior researches assumed about the direct link of objective type career success with life satisfaction, 
moreover this direct link is really based on goals of an employee what he or she actually want to achieve from career (Malka and Chatman, 2003). There was study conducted at international level entailing on 32000 of sample size among full time employee from diverse organizations and concluded that $35 \%$ of sample size are engaged fully (Bilal, Yawar \& Zaman, 2020). In this connection, Jones (2017) said that same kind of study was conducted to analyze the proportion of disengagement and engagement of workers in Australia and New Zealand and there was result about $20 \%$ of employees in Europe, Australia and New Zealand were engaged fully but in India $10 \%$.

According to study of Rehman, Alvi and Ahmad (2021) about 21.6\% peoples are highly satisfied from their lives and about $54.4 \%$ peoples are satisfied at moderating level but $21 \%$ peoples are highly dissatisfied from their lives. Particularly in Europe, the majority peoples are dissatisfied from their level of the lives. According to Akhter, Kayani \& Tahir, (2020) suggested that the dissatisfaction of life is being found more among the people with low level of income. In China researchers such as Taris, Beek and Schaufeli (2020) found that old age peoples are also highly dissatisfied from their lives. Özsoy, Uslu and Öztürk (2014) said that in Turkey almost 50\% employees in public and private sector are dissatisfied from their lives. In this connection, it is can be concluded that the satisfaction about the life is very critical for employees as well as for organization. From the best of researcher knowledge, previous researches relationship of the shyness with career success and the life satisfaction and career success with life satisfaction individually but no study proposed these variables in the single model. Similarly, no previous research finds the mediating effect of career success for relationship of the shyness with life satisfaction.

\section{Life Satisfaction}

Life Satisfaction (LS) does not look like an ongoing affective self-evaluation or even a certain reaction to different events occurs in a human life. Instead of that it is being considered as the cognitive process involving global judgments about individual's overall quality of life (Diener, Suh, Lucas \& Smith, 1999), the causal logic underlying such judgments can be described from either a top-down or a bottom-up perspective (Diener et al., 1985), approaches that are subject of the vibrant discourse in extant literature (Mallard, Lance \& Michalos, 2017), the top-down causal perspective views LS in static, trait-like terms (Lent \& Brown, 2008) and supposes that LS leads to certain outcomes, such as satisfaction with the particular life domain (Headey \& Muffels, 2018) and in other words, persons are (say) satisfied with their job because they are mainly satisfied with life-and not vice versa, from bottom-up perspective, in contrast, certain variables cause LS; thus individuals are satisfied overall because of their aggregate satisfaction with various aspects or domains in their life" (Lance, Lautenschlager, Sloan \& Varca, 1989). For example different aspects can be added such as job satisfaction (Judge \& Watanabe, 1993), health satisfaction (Dolan, Peasgood \& White, 2008), family satisfaction (Schimmack \& Oishi, 2005).

According the researchers like Veloso-Besio et al., (2015) health and mental approach are very critical components to be affected through the job satisfaction. Life satisfaction is the core function, which is directly linked with the calm life of the employees at personal level as well as the professional level. It does not only motivate the employees to work with the high care and effectively but also encourage them to accomplish the high-valued tasks to gain the highest achievements. Life satisfaction is also considerable the emotional response of employees about their free time and their lives (Chung, \& Kim, 2017; Akhter et al.,, 2020). That's why the life 
satisfaction is very important for every organization. Satisfaction is being considered as one of major part of life satisfaction (Yu, Sirgy, Bosnjak \& Lee, 2020). In this connection, according to Yilmaz et al. (2008) life satisfaction has the power to divide the complete life of any individual. It is needed to set the priorities, which required extra effort and care to attain life targets and also to achieve the desired life. Subsequently, it is needed to understand the other main aspects such as decreased softness and solidity and also the process to analyze the level of the mind (Lightsey, McGheeet al., 2013). Therefore, life satisfaction is also enables you to attach your satisfaction with particular circumstances of life such as wellbeing reaction like pleasure, high passion and to remain positive about routine life relations and happenings (Avşaroğlu \& Okutan, 2018).

\section{Shyness}

According to Odaci \& Celik (2013) and Tian, Bian, Han, Gao and Wang (2017) shyness is the critical precursor element of PIU and also the mobile phone addiction (Han, Geng, Jou, Gao \& Yang, 2017). It is also acknowledged in social withdraw research, "shyness is a temperamental disposition that refers to the tendency to wariness, discomfort and inhibition in the presence of novelty social environment, especially in those involving social appraisals and evaluations by authority" (Melchior \& Cheek, 1990) and Campbell (1896) described shyness as "excessive self-consciousness and very generally, excessive sensitiveness as to what others may think of personality of sufferer". In this connection, shyness is the vital predictor fot diverse outcomes. It is basically the situation of feeling awkward, worried and tensed in presence of others or even inverse understanding of oneself to take him/her in a discomfort situation. The shyness consists on different cognitive factors like excessive negative self evaluation, affective factors like social anxiety and heightened feelings of the personal, physiological factors like sweating, blushing, increased heartbeat, trembling, stammering, upset stomach and increased urinary and behavioral factors like poor communication skills and improper retort (Schwerdtfeger et al., 2020).

Asendorpf (1990) said that shyness also consist on the social avoidance and social approach. Shyness does have bad impact on pleasing the situation and communication and commonly shy peoples do face anxiety disorder and poor communications issues (Ameringen et al., 1998), loneliness type feelings (Tan et al.,, 2016; Zhao, Kong \& Wang, 2013), and also the depression (Han et al., 2017). It is linked also with hidden participation in certain activities to pursue career goals effectually. It is basically situation of feeling awkward, worried and tensed in the presence of others or even inverse understanding of oneself to take him or her in a discomfort situation. The shyness is the characteristic of a human, which is the situation of being remain reserve and feeling discomfort in social setup. Shyness is a feeling of fear or discomfort caused by other people, especially in new situations or among strangers. It's an unpleasant feeling of self-consciousness fear of what some people believe others are thinking. To avoid such inverse feelings, few shy individuals involve themselves in mobile phone usage, which latterly make them addicted of mobile phone (Bian \& Leung, 2015; Poupis et al., 2021). Such situation shows that mobile phone addiction is similar to internet addiction (Perez et al., 2012; Huang et al., 2020).

\section{Career Success}

According to Shockley, et al. (2016) career success is a continued process whole through the life makeover and changes right from the childhood, schooling, and professional working life and in the end retirement. Career is based on variety of stages, where an individual reach through 
different life issues and experiments (Schreuder and Coetzee, 2011). As per the Cave (2015) throughout the career process an individual has to measure, make immediate decision and to take career based different actions at multiple times as to achieve multiple career paths during the life span. Holland (1985) described the career success, how an individual fit in environment and disclosed multiple career judgment evaluations techniques which are still effective and very much useful in today's life. It is personal growth of individual (Gottfredson, 2002). Brown (2002) has defined career success as wider life actions. As per Diriye (2017) it is the consistent improvement of the working life. According to Wilkins et al., (2014) career success is consistent accomplishment and even improvement of different skills, knowledge, job expertise and also the professional development, which is associated with the career based effective planning and implementation of activities. It is the human resource management and its effective usage in private and public sector (Armstrong, 2006). Same career development is most considered topic among academia circle. Armstrong (2006) said that career success is basic tool for enhanced learning.

Training is not considered the only technique to improve the skills of employees to accomplish the job tasks; instead it is organizational commitment towards their employee's development. Ullah et al. (2020) career success is very critical for individuals as well as for the organization. It is also considered the most effective tool for excellent outcome as an individual and also organization. According to Kareem (2019) all the organizations try to hire, retain and also to sustain the work force to achieve the competitive edge and market targetswhether employees are motivated to have improved career options through polishing and enhancing their working proficiencies. As per the "management study guide for career success Diriye (2017) in a world full of aspirations, workforces are career cognizant and they stay anchored to business of the organization which affords them avenue to display their talents, grow vertically and accomplish their objectives, growth is not definitive term, rather relative, whereby translated differently by different people". Consequently, for some individuals it could be big remuneration package, instead other may consider it is to attain the top rank position and even few of them may consider the attainment of improved skills and techniques in profession and also as human as well.

Figure 1 Hypothesized Research Model

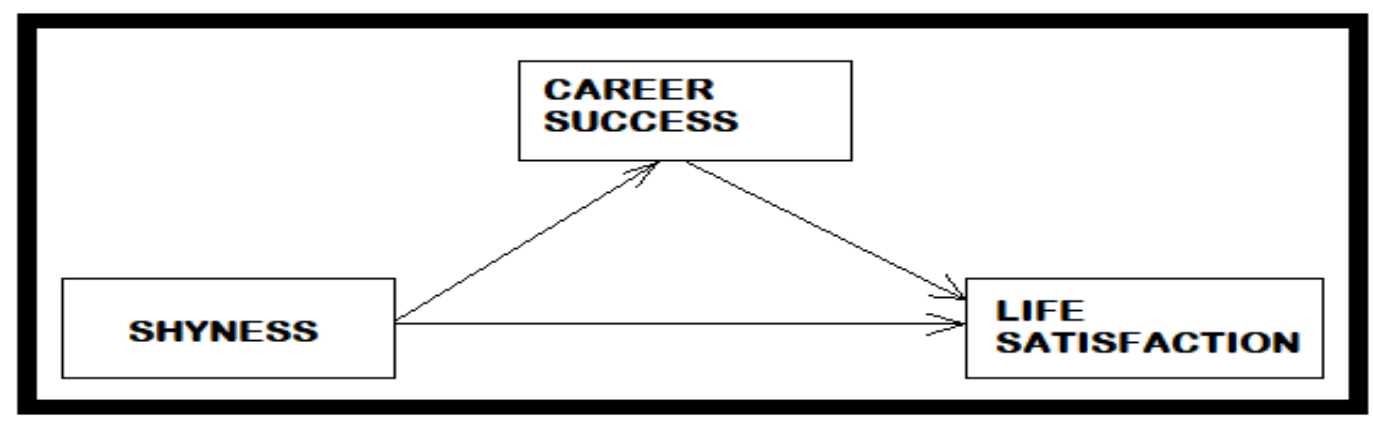

\section{Theoretical Framework}

Adaptation-level theory Brickman et al. (1978) describes the phenomenon of life satisfaction. This theory describes that life events can be judged as satisfying or dissatisfying as they actually occur. On the basis of Adaptation-level theory, Bowling, Beehr, Wagner and Libkuman, (2005) 
proposed that career success has relation with life satisfaction. This study is an adaptation-level theory and adopted viewed of Ye et al. (2019) that the shyness had negative influence on life satisfaction.

\section{Research Hypothesis}

The study was based on certain assumptions and thus according to Ye et al. (2019), shyness has negative influence on life satisfaction. Consequently, current research proposes the following hypotheses.

$\mathrm{H}_{1}$ : The shyness has the negative influence/effect on life satisfaction in the particular context.

According to Phillips and Bruch (1988), shyness has negative influence on the career success. Consequently, the current research proposes the following hypotheses based upon the existing research.

$\mathrm{H}_{2}$ : The shyness has negative influence/effect on career success in context under considerations. According to Choi and Nae (2020), Diener and Biswas-Diener, (2002) and Zhang et al., (2011), career success has positive influence on life satisfaction. So, current research proposes following hypotheses.

$\mathrm{H}_{3}$ : The career success has negative influence/effect on life satisfaction in context under study. $\mathrm{H}_{4}$ : Career success act as intervening variable for the relationship of shyness and career success.

\section{RESEARCH METHODOLOGY}

Life satisfaction was measured by the life satisfaction Scale (Diener et al., 1985), which consists of 5 items. Shyness was measured by shyness Scale (Cheek \& Buss 1981), which consists of 13 items. We measured employees' perception of career success with the five-item scale of career satisfaction developed by Greenhaus et al. (1990). All the responses were taken on 5-point Likert scale.

\section{Research Design}

This is the cross-sectional study as data is collected from customers of at single time point. This is explanatory research because relationships are based on cause and effect and relationships are existed previously beside mediation effect. Employees of telecom sector are target population. Data is collected from 252 employees of telecom sector who are working in Lahore are selected randomly.

\section{Population \& Sample}

The population is entire elements includes employees of UFone and Telenoor who are working in Islamabad. Thus, 252 employees of telecom sector are randomly selected for collecting the data.

\section{RESULT AND DISCUSSION}

Reliability of data is based upon value of Cronbach's Alpha i.e.>0.50. the value of Cronbach's Alpha of the career success, shyness and the brand life satisfaction are $0.79,0.75$ and 0.82 respectively. 
Table 1

Correlation Analysis

\begin{tabular}{lccc}
\hline & Shyness & Career Success & Life Satisfaction \\
\hline Shyness & 1 & & \\
Career Success & $-0.37^{* *}$ & 1 & \\
\hline Life Satisfaction & $-0.32^{* *}$ & $0.46^{* *}$ & 1 \\
\hline
\end{tabular}

Correlation analysis explains the kind of relationship between the variables. Table no 3 shows that $\mathrm{r}=-0.37$ for shyness and career success. This shows that negative significant relationship with one another. " $r$ " of correlation $=-0.332$ for shyness and life satisfaction which indicates that negative significant relationship with one another. " $\mathrm{r}$ " of correlation $=0.306$ for life satisfaction and career success. This shows that these variables positive significant relationship with one another.

\section{RESULTS AND DISCUSSION}

Table 2

Regression Analysis

\begin{tabular}{|c|c|c|c|c|c|}
\hline & $\beta$ & S.E & $\mathrm{F}$ & $\mathrm{R} 2$ & Decision \\
\hline \multicolumn{6}{|l|}{ Path c( Step 1) } \\
\hline \multicolumn{6}{|l|}{ Outcome: Life Satisfaction } \\
\hline Predictor: Shyness & -0.38 & .086 & 70.83 & 0.31 & $0.000<0.01$ \\
\hline \multicolumn{6}{|l|}{ Step 2 (Path a) } \\
\hline \multicolumn{6}{|l|}{ Outcome: Career Success } \\
\hline Predictor: Shyness & -0.43 & 0.84 & 125.25 & 0.29 & $0.000<0.01$ \\
\hline \multicolumn{6}{|l|}{ Step 3A (Path b) } \\
\hline Outcome: LS, Predictor: CS (Path c') & 0.48 & 0.91 & 164.35 & 0.36 & $0.000<0.01$ \\
\hline Mediator: Career Success & 0.26 & 0.056 & & & $0.001<0.10$ \\
\hline Predictor: Shyness & -0.29 & 0.066 & & & $0.000<0.01$ \\
\hline
\end{tabular}

$\mathrm{P}<0.01, \mathrm{P}<0.05 \& \mathrm{P}<0.10$

Table provides the values of regression analysis. For relationship of shyness with life satisfaction, Value of $\mathrm{F}$ is 70.83 and $\mathrm{R} 2=0.31$ and Value of $\beta=-0.38$, value of $\mathrm{p}<0.01$, So hypothesis no 1about this relationship is accepted. This result is similar with the result of Ye et al. (2019). For the relationship of shyness with career success, Value of $F$ is 125.25 and R2 $=0.29$ and Value of $\beta=-0.51$. Value of $\mathrm{p}<0.01$, So, hypothesis no 2 about this relationship is accepted. This result is similar with the result of Phillips and Bruch (1988). In this connection. for the relationship of career success with life satisfaction, Value of $F$ is 164.34 and $R 2=0.36$ and Value of $\beta=-0.48$. value of $\mathrm{p}<0.01$, So, hypothesis No. 2 about this relationship is accepted). In this regard, this result is similar with the result of Choi and Nae (2020), Diener and Diener, (2002), Zhang et al. (2011).

For checking the mediation influence of career success for the relation of shyness with life satisfaction, Current research analyses the three direct relationships. Table no 3 describes that all these relationships are significant. For evaluating mediation effect, current research regresses the independent variable (shyness) with mediator variable (career success) on life satisfaction. 
It is observed that Value of $\beta$ is reduces from -0.38to -0.29. This value describes that mediation is exist for the relation of shyness with life satisfaction, but this is partial mediation. This is finding of the current research. This result is also logically justified as if we decrease the level of shyness by increasing the level of the career success the level of the life satisfaction will bealso elevated.

\section{CONCLUSION}

There are many organizations whose employees are not satisfied with their lives. This may create problem in term of their productivity and affiliation of their jobs. The present study thus provides significant information in concluding the study and reaching the decision. The current research is based upon the employees of telecom sector of Lahore Pakistan. Current research proposes four hypotheses. Three of hypotheses are about direct relationships and one is about the mediation effect of career success for the relation of shyness with life satisfaction. All the hypotheses are accepted. Moreover, career success partially mediates the relation of shyness with life satisfaction. In future, thesetypes of studies may conduct on other sectors likebanking sector;textile sector and education sector for validate the results. It is also worthwhile to collect data from employees of Government sectorof employees. In this connection, for generalizing the results data may also be collected from different cities likewise Islamabad, Faisalabad and Karachi.

\section{REFERENCES}

Akhter, N., Kayani, U. S., \& Tahir, M. (2020). Mediating Role Of Employees Job Engagement For Relation Of Emotional Labor With Life Satisfaction. Gomal University Journal of Research, 36(2).

Ameringen, M., Mancini, C., \& Oakman, J. M. (1998). The relationship of behavioral inhibition and shyness to anxiety disorder. The Journal of nervous and mental disease, 186(7), 425-431.

Armstrong, S. M. (2006). The determinants of how managers cope with the organisational downsizing. Applied Psychology, 55(1), 1-26.

Asendorpf, J. B. (1990). Beyond the social withdrawal: Shyness, unsociability, and peer avoidance. Human development, 33(4-5), 250-259.

Avşaroğlu, S., \& Okutan, H. (2018). Zihin engelli çocuğu olan ailelerin yaşam doyumları, iyimserlik ve psikolojik belirti düzeylerinin incelenmesi. Manas Sosyal Araştırmalar Dergisi, 7(1), 59-76.

Bian, M., \& Leung, L. (2015). Linking loneliness, shyness, smartphone addiction symptoms, and patterns of smartphone use to social capital. Social science computer review, 33(1), 61-79.

Bilal, R. U., Yawar, R. B., \& Zaman, H. M. F. (2020). Relationship Of Personal Resilience And Job Satisfaction Through the lens of employee engagement. Academic Journal of Social Sciences, 4(2), 364-376.

Bowling, N. A., Beehr, T. A., Wagner, S. H., \& Libkuman, T. M. (2005). Adaptation-level theory, opponent process theory, and dispositions: an integrated approach to the stability of job satisfaction. Journal of Applied Psychology, 90(6), 1044.

Brickman, P., Coates, D., \& Bulman, R. (1978). Lottery winners and accident victims: Is happiness relative?. Journal of personality and social psychology, 36(8), 917.

Brown, D. (2002). The role of work and cultural values in occupational choice, satisfaction, and success: A theoretical statement. Journal of counseling \& development, 80(1), 48-56. 
Campbell, H. (1896). Morbid shyness. The British Medical Journal, 805-807.

Cave, P. (2015). Internationalising Japan: Discourse and Practice ed. by Jeremy Breaden, Stacey Steele, and Carolyn S. Stevens. The Journal of Japanese Studies, 41(2), 468-473.

Cheek, J. M., \& Buss, A. H. (1981) Shyness and sociability. Journal of Personality and Social Psychology, 41, 330-339.

Cheek, M., \& Melchior, L. (1990). Shyness, self-esteem, and self-consciousness. In Handbook of social and evaluation anxiety (pp. 47-82). Springer, Boston, MA.

Choi, B. K., \& Nae, E. Y. (2020). When career success enhances employees' life satisfaction: different effects of two types of goal orientations. Personnel Review.

Chung, S., \& Kim, M. (2017). Anger factors impacting on life satisfaction of mothers with young children in Korea: Does mother age matter? Personality and individual differences, 104, 190-194.

Coetzee, M., \& Schreuder, D. (2011). The relation between career anchors, emotional intelligence and employability satisfaction among workers in service industry. Southern African Business Review, 15(3), 76-97.

Diener, E., Emmons, R. A., Larsen, R. J., \& Griffin, S. (1985). The satisfaction with life scale. Journal of Personality Assessment, 49(1), 71-75.

Diener, E., Napa-Scollon, C. K., Oishi, S., Dzokoto, V., \& Suh, E. M. (2000). Positivity and the construction of life satisfaction judgments: Global happiness is not sum of its part. Journal of happiness studies, 1(2), 159-176.

Diener, E., Suh, E. M., Lucas, R. E., \& Smith, H. L. (1999). Subjective well-being: Three decades of progress. Psychological bulletin, 125(2), 276.

Diener, R., \& Diener, E. (2009). Making the best of a bad situation: Satisfaction in the slums of Calcutta. Culture and well-being, 261-278.

Diriye, A. (2019). The role of social capital in knowledge sharing in higher education institutes. Electronic Journal of Knowledge Management, 17(2), 158-170.

Dolan, P., Peasgood, T., \& White, M. (2008). Do we really know what makes us happy? A review of economic literature on factors associated with subjective well-being. Journal of economic psychology, 29(1), 94-122.

Erol, R. Y., \& Orth, U. (2017). Self-esteem and the quality of romantic relationships. European Psychologist. 21, 274-283

Ferrer, S. C. (2017). The relationship between Gratitude and Life satisfaction in a sample of Spanish university students. Anales de Psicología/Annals of Psychology, 33(1), 114-119.

Gigantesco, A., Fagnani, C., Toccaceli, V., Stazi, M. A., Lucidi, F., Violani, C., \& Picardi, A. (2019). The relationship between satisfaction with life and depression symptoms by gender. Frontiers in psychiatry, 10, 419.

Gottfredson, L. S. (2002). Gottfredson's theory of circumscription, compromise, and self-creation. Career choice and development, 4, 85-148.

Greenhaus, J. H., Parasuraman, S., \& Wormley, W. M. (1990). Effects of race on organizational experiences, job performance evaluations, and career outcomes. Academy of Management Journal, 33 (1), 64-86.

Han, C. K., \& Hong, S. I. (2011). Assets and life satisfaction patterns among Korean older adults: Latent class analysis. Social Indicators Research, 100(2), 225-240.

Han, L., Geng, J., Jou, M., Gao, F., \& Yang, H. (2017). Relationship between shyness and mobile phone addiction in Chinese young adults: Mediating roles of self-control and attachment anxiety. Computers in Human Behavior, 76, 363-371. 
Headey, B., \& Muffels, R. (2018). A theory of life satisfaction dynamics: Stability, change and volatility in 25-year life trajectories in Germany. Social Indicators Research, 140(2), 837-866.

Henderson, L., Gilbert, P., \& Zimbardo, P. (2014). Shyness, social anxiety, and social phobia. In Social anxiety (pp. 95-115). Academic Press.

Hintikka, J., Koskela, T., Kontula, O., Koskela, K., Koivumaa-Honkanen, H. T., \& Viinamäki, H. (2001). Religious attendance and life satisfaction in Finnish general population. Journal of Psychology and Theology, 29(2), 158-164.

Holland, J. L. (1985). Making vocational choices: A theory of vocational personalities and work environments (2nd ed.). Englewood Cliffs, NJ: Prentice Hall

Huang, H. Y., Demetriou, S., Banerjee, R., Tuncay, G. S., Gunter, C. A., \& Bashir, M. (2020). Smartphone Security Behavioral Scale: A New Psychometric Measurement for Smartphone Security. arXiv preprint arXiv:2007.01721.

Jawahar, I. M., \& Liu, Y. (2017). Why are proactive people more satisfied with their job, career, and life? An examination of the role of the work engagement. Journal of Career Development, 44(4), 344-358.

Jones, B. A. (2017). Invasive species impacts on human well-being using the life satisfaction index. Ecological Economics, 134, 250-257.

Judge, T. A., \& Mueller, J. D. (2012). The job attitudes. Annual review of psychology, 63, 341-367.

Judge, T. A., \& Watanabe, S. (1993). Another look at the job satisfaction-life satisfaction relationship. Journal of applied psychology, 78(6), 939.

Kareem, M. A. (2019). The impact of human resource development on organizational effectiveness: empirical study. Management Dynamics in the Knowledge Economy, 7(1), 29-50.

Keyes, C.L.M., Shmotkin, D., Ryff, C., (2002). Optimizing well-being: the empirical encounter of two traditions. Journal of Personal Sococial Psychology. 82, 1007-1022.

Lance, C. E., Lautenschlager, G. J., Sloan, C. E., \& Varca, P. E. (1989). A comparison between bottom-up, top-down, and bidirectional models of relationships between global and life facet satisfaction. Journal of Personality, 57(3), 601-624.

Lee, H. (2020). Working hours and life satisfaction: finding blind spots from Korean panel data. International Review of Public Administration, 1-18.

Lent, R. W., \& Brown, S. D. (2008). "Social cognitive career theory and subjective well-being in the context of work." Journal of Career Assessment 16, (1), 6-21.

Li, C., Chi, I., Zhang, X., Cheng, Z., Zhang, L., \& Chen, G. (2015). Urban and rural factors associated with life satisfaction among older Chinese adults. Aging \& Mental Health, 19(10), 947-954.

Lightsey, O. R., McGhee, R., Ervin, A., Gharghani, G. G., Rarey, E. B., Daigle, R. P., ... \& Powell, K. (2013). Self-efficacy for affect regulation as a predictor of future life satisfaction and moderator of the negative affect-Life satisfaction relationship. Journal of Happiness Studies, 14(1), 1-18.

Malka, A., \& Chatman, J. A. (2003). Intrinsic and extrinsic work orientations as moderators of the effect of annual income on subjective well-being: A longitudinal study. Personality and Social Psychology Bulletin, 29(6), 737-746.

Mallard, A. G., Lance, C. E., \& Michalos, A. C. (2017). Culture as a moderator of overall life satisfaction-Life facet satisfaction relationships. In Connecting the Quality of Life Theory to Health, Well-being and Education (pp. 59-79). Springer, Cham. 
Maynard, D. C., \& Joseph, T. A. (2008). Are all part-time faculty underemployed? The influence of faculty status preference on satisfaction and commitment. Higher education, 55(2), 139-154.

Nie, Q., Tian, L., \& Huebner, E. S. (2019). Relations among Family Dysfunction, Loneliness and Life Satisfaction in Chinese Children: A Longitudinal Mediation Model. Child Indicators Research, 1-24.

Odacı, H., \& Çelik, Ç. B. (2013). Who are problematic internet users? An investigation of the correlations between problematic internet use and shyness, loneliness, narcissism, aggression and self-perception. Computers in Human Behavior, 29(6), 2382-2387.

Özsoy, E., Uslu, O., \& Öztürk, O. (2014). Who are happier at work and in life? Public sector versus private sector: A research on Turkish employees. International Journal of Recent Advances in Organizational Behaviour and Decision Sciences, 1(2), 148-160.

Pan, J., \& Zhou, W. (2013). Can success lead to happiness? The moderators between career success and happiness. Asia Pacific Journal of Human Resources, 51(1), 63-80.

Phillips, S. D., \& Bruch, M. A. (1988). Shyness and dysfunction in career development. Journal of Counseling Psychology, 35(2), 159.

Poupis, L. M., Rubin, D., \& Lteif, L. (2021). Turn up the volume if you're feeling lonely: The effect of mobile application sound on consumer outcomes. Journal of Business Research, 126, 263-278.

Rehman, Z. U., Alvi, A. K., \& Ahmad, Z. (2021). The Relationship of Hope with Life Satisfaction through the Path of Resilience. Research Journal of Social Sciences and Economics Review, 2(1), 303-316.

Rohrer, J. M., Richter, D., Brümmer, M., Wagner, G. G., \& Schmukle, S. C. (2018). Successfully striving for happiness: Socially engaged pursuits predict increases in life satisfaction. Psychological Science, 29(8), 1291-1298.

Rowsell, H. C., \& Coplan, R. J. (2013). Exploring links between shyness, romantic relationship quality, and well-being. Canadian Journal of Behavioural Science/Revue canadienne des sciences du comportement, 45(4), 287.

Schwerdtfeger, A. R., Rominger, C., \& Obser, P. D. (2020). A shy heart may benefit from everyday life social interactions with close others: An ecological momentary assessment trial using Bayesian multilevel modeling. Biological psychology, 152, 107864.

Shockley, K. M., Ureksoy, H., Rodopman, O. B., Poteat, L. F., \& Dullaghan, T. R. (2016). Development of a new scale to measure subjective career success: A mixed-methods study. Journal of Organizational Behavior, 37(1), 128-153.

Siebert, J. U., Kunz, R. E., \& Rolf, P. (2020). Effects of proactive decision making on life satisfaction. European Journal of Operational Research, 280(3), 1171-1187.

Sun, R. C., \& Shek, D. T. (2010). Life satisfaction, positive youth development, and problem behaviour among Chinese adolescents in Hong Kong. Social Indicators Research, 95(3), 455-474.

Sun, R. C., \& Shek, D. T. (2012). Positive youth development, life satisfaction and problem behaviour among Chinese adolescents in Hong Kong: a replication. Social indicators research, 105(3), 541-559.

Tan, J., Ai, Y., Wen, X., Wu, Y., \& Wang, W. (2016). Relationship between shyness and loneliness among Chinese adolescents: Social support as mediator. Social Behavior and Personality: An international journal, 44(2), 201-208. 
Taris, T. W., van Beek, I., \& Schaufeli, W. B. (2020). The motivational make-up of workaholism and work engagement: A longitudinal study on need satisfaction, motivation, and heavy work investment. Frontiers in Psychology, 11, 1419.

Tian, Y., Bian, Y., Han, P., Gao, F., \& Wang, P. (2017). Associations between psychosocial factors and generalized pathological internet use in Chinese university students: A longitudinal cross-lagged analysis. Computers in Human Behavior, 72, 178-188.

Tremblay, M., Dahan, J., \& Gianecchini, M. (2014). The mediating influence of career success in relationship between career mobility criteria, career anchors and satisfaction with organization. Personnel Review. 43(6), 2014, 818-844

Ullah, A., Aziz, A., \& Ibrahim, H. (2020). A Systematic Review of Employee Retention: What's Next in Pakistan?. Journal of Contemporary Issues and Thought, 10, 36-45.

Veloso, C., Cuadra-Peralta, A., Gil-Rodriguez, F., Quiroz-Cornejo, A., \& Meza-Castro, S. (2015). Workers training: Impact of a program based on positive psychology and social skills, on life satisfaction, job satisfaction and organizational climate Capacitación en trabajadores: Impacto de un programa, basado en psicología positiva y habilidades socia.

Wang, Y., \& Kong, F. (2014). The role of emotional intelligence in the impact of mindfulness on life satisfaction and mental distress. Social indicators research, 116(3), 843-852.

Wang, Y., Tian, L., Guo, L., \& Huebner, E. S. (2020). Family dysfunction and Adolescents' anxiety and depression: A multiple mediation model. Journal of Applied Developmental Psychology, 66, 101090.

Wilkins, K. G., Santilli, S., Ferrari, L., Nota, L., Tracey, T. J., \& Soresi, S. (2014). The relationship among positive emotional dispositions, career adaptability, and satisfaction in Italian high school students. Journal of Vocational Behavior, 85(3), 329-338.

Xiang, Y., Yuan, R., \& Zhao, J. (2020). Childhood maltreatment and life satisfaction in adulthood: the mediating effect of emotional intelligence, positive affect and negative affect. Journal of health psychology, 1359105320914381.

Ye, B., Li, L., Ma, T. L., Gao, L., Sheen, D. C., Liu, M., ... \& Yang, Q. (2019). The Effect of shyness on life satisfaction among Chinese college students: A moderated mediation model. Current Psychology, 1-9.

Yilmaz, E. (2008). Organizational commitment and loneliness and life satisfaction levels of school principals. Social Behavior and Personality: An international journal, 36(8), 1085-1096.

Yu, G. B., Sirgy, M. J., Bosnjak, M., \& Lee, D. J. (2021). A Preregistered study of the effect of shopping satisfaction during leisure travel on satisfaction with life overall: The mitigating role of financial concerns. Journal of Travel Research, 60(3), 639-655.

Zhang, F., Zhang, C., \& Hudson, J. (2018). Housing conditions and life satisfaction in urban China. Cities, 81, 35-44.

Zhang, J. W., \& Howell, R. T. (2011). Do time perspectives predict unique variance in life satisfaction beyond personality traits?. Personality and individual differences, 50(8), 1261-1266.

Zhao, J., Kong, F., \& Wang, Y. (2013). The role of social support and self-esteem in the relationship between shyness and loneliness. Personality and Individual Differences, 54(5), 577-581. 